\title{
Physico-chemical changes in peach fruit during storage
}

\author{
SUMMY ULLAH* AND S.K. JAWANDHA \\ Department of Fruit Science, Punjab Agricultural University, LUDHIANA (PUNJAB) INDIA \\ Email : summymau@gmail.com \\ *Author for Correspondence \\ Research chronicle : Received : 26.08.2015; Revised : 01.11.2015; Accepted : 28.11.2015
}

\begin{abstract}
SUMMARY :
Peach undergoes various ripening changes after harvest and the magnitude of post-harvest losses in fresh fruits is extraordinarily high resulting in proportionately higher economic losses than that of pre-harvest losses. An attempt was made to reduce these losses in which physiologically mature, uniform and healthy fruits of peach cv. SHAN-I-PUNJAB were harvested and treated for 5-minutes in aqueous solutions of spermidine, spermine and putrescine at three different concentrations viz., 1.0, 2.0 and $3.0 \mathrm{mmol} \mathrm{L}^{-1}$ and treated fruits were packed in CFB boxes before storage at 0 to $1^{\circ} \mathrm{C}$ and 90 95 per cent RH for 32 days. Results revealed that post-harvest treatments of spermidine, spermine and putrescine were effective in delaying ripening and extending the post-harvest life of peach fruits under cold storage conditions. Putrescine @ $3 \mathrm{mmol} \mathrm{L}^{-1}$ treatment was found most effective in decreasing physiological loss in weight (PLW) and spoilage and maintaining the high palatability, TSS: acid and total sugars at the end storage period.
\end{abstract}

KEY WORDS : Peach, Storage, PLW, Sugar, Quality, Spermidine, Spermine, Putrescine

How to cite this paper : Ullah, Summy and Jawandha, S.K. (2015). Physico-chemical changes in peach fruit during storage. Internat. J. Proc. \& Post Harvest Technol., 6 (2) : 172-176. 